\title{
Floristic Composition and Community Analysis of Komto Afromontane Moist Forest, East Wollega Zone, West Ethiopia
}

\author{
Fekadu Gurmessa $^{1 *}$, Teshome Soromessa $^{2}$ and Ensermu Kelbessa ${ }^{2}$ \\ ${ }^{1}$ Department of Biology, Wollega University, Post Box No: 395, Nekemte, Ethiopia \\ ${ }^{2}$ Addis Ababa University, Post Box No: 1176, Addis Ababa, Ethiopia.
}

\begin{abstract}
This study was conducted on Komto Forest in East Wollega Zone, Oromia National Regional State, west Ethiopia with the objective of determining the floristic composition and community type of the forest. Systematic sampling method was used to collect vegetation data. Accordingly, 53 quadrats each with $400 \mathrm{~m}^{2}(20 \mathrm{~m} \mathrm{X} 20 \mathrm{~m})$ for woody species and subplots of $1 \mathrm{~m} \times 1 \mathrm{~m}$ within the main plots for herbaceous plants were laid along line transects radiating from the peak of Komto Mountain in 8 directions. All plots (quadrats) were laid at a distance of $200 \mathrm{~m}$ along the transect lines. In each of these quadrats, all vascular plant species were collected and brought to ETH for identification. Vegetation classification was performed using PC-ORD software packages. Sorensens's similarity coefficient and Shannon-Wiener diversity index were also used to detect similarities among communities and to compute species richness and evenness between the plant communities respectively. A total of 180 species in 151 genera and 66 families were identified from the forest out of which 31 were new records from Wollega (WG) floristic region for the flora of Ethiopia and Eritrea. Fabaceae and Asteraceae are the dominant families in terms of species richness. Furthermore, 18 endemic species some of which are under the Red Data List of IUCN were also identified. In this study, four plant communities were identified and described. Phytogeographical comparison of Komto Forest revealed the highest similarity with moist mountain forests which asserts that Komto Forest is one of the moist mountain Forests in Ethiopia. Therefore, based on the results of this study, detailed ecological studies in relation to various environmental factors such as soil type and properties, ethnobotanical studies to explore indigenous knowledge on the diverse uses of plants, and sound management and monitoring as well as maintenance of biodiversity that promote sustainable use of the forest and its products are recommended.

Article Information Article History:

Received : 02-04-2013

Revised : 20-06-2013

Accepted : 22-06-2013

\section{Keywords:}

Species richness

Komto forest

Plant community

East Wollega Zone

Moist mountain forest

${ }^{*}$ Corresponding Author:

Fekadu Gurmessa

E-mail:

gurmessa.fekadu@yahoo.com
\end{abstract}

\section{INTRODUCTION}

Ethiopia is found in the horn of Africa and located between $3^{0} 24$ and $14^{\circ} 53^{\prime}$ North and $32^{\circ} 42^{\prime}$ and $48^{0} 12$ East with a total area of 1.12 million $\mathrm{km}^{2}$ (MoA, 2000). The Altitudinal range of the country varies from $110 \mathrm{~m}$ below sea level at Kobar sink in Afar to $4620 \mathrm{~m}$ a.s.l, the highest peak of Ras Dejen (IBC, 2008). The topography and diverse climatic conditions of Ethiopia led to the emergence of habitats that are suitable for evolution. These have led to the occurrence of some unique plant and animal species and their assemblages. As a result, Ethiopia is one of the countries in the world with high level of biodiversity. Owing to the long history of agriculture and the diversity of the environment,
Ethiopia is again one of the 12 Vavilov centers of crop genetic diversity (Zerihun Woldu, 2008).

According to Ensermu Kelbessa et al. (1992); Sebsebe Demissew et al. (1996); Friis and Sebsebe Demissew, (2001); Sebsebe Demissew et al. (2004); Sebsebe Demissew and Friis, 2009, the vegetation of Ethiopia is divided into eight major types: Desert and Semi-desert Scrubland, AcaciaCommiphora Woodland, Moist evergreen Montane Forest, Low land semi-evergreen forest, Combertum-Terminalia Woodland, Dry evergreen Montane Forest, Afroalpine and Sub-Afroalpine Vegetation and Riparian and Wetland Vegetation. 
Fekadu Gurmessa et al.,

The moist evergreen forest ecosystem is the most diverse ecosystem in composition, structure and habitat types (NBSAP, 2005). This Forest comprises the humid forest in the southeastern plateau, Harenna Forest, (Lisanework Nigatu and Mesfin Tadesse, 1989) and Mana Angetu (Ermias Lulekal et al., 2008) and high forests of the country mainly the southwest forests. Several researchers such as Hailu Sharew, 1982; Lisanework Nigatu and Mesfin Tadesse, 1989; Zerihun Woldu et al., 1989; Friis, 1992; Kumlachew Yeshitila and Tamrat Bekele, 2002 Ensermu Kelbessa and Teshome Soromessa, 2008; Woldeyohannes Enkossa, 2008 have studied the composition and structure of this forest vegetation type in southern, southwest and western part of the country and described them on floristic basis.

Forest cover in Ethiopia has been declining rapidly due to anthropogenic impacts such as uncontrolled expansion of agriculture and overgrazing. Although a substantial proportion of the land area in high land Ethiopia was once believed to have been covered by forest (Friis, 1992), now a days the forest cover of the country is less than $3 \%$. Ensermu Kelbessa et al. (1992) stated that in Ethiopia, limitations to the opportunities for income generation caused by ecological and socioeconomic constraints forced people to cultivate marginal lands and allow overgrazing and the felling of trees, thus catalyzing a spiral of environmental degradation and deforestation. The overall result of this environmental degradation in Ethiopia, whether at a local or ecosystem level, leads to desertification and its manifestations are eventually becoming the overriding cause for the loss of biodiversity.

Loss of forest cover and biodiversity due to human-induced activities is a growing concern in many parts of the world (Feyera Senbeta and Demel Teketay, 2003). To alleviate such losses, due attention is given to the establishment of natural reserves around the world (Groombridge, 1992; Pimbert and Pretty, 1995; WRI et al., 1998). Komto Forest, one of the 58 National Forest Priority Areas (NFPAs), was also established for a similar purpose though it is not well managed and most of the forest area is degraded and converted to agricultural land. This might be the lack of integration of the local people living around the conservation areas into the conservation efforts. Therefore, the objectives of this study was to document the floristic composition of the forest, to classify the forest vegetation into plant community types, to determine the diversity of the different community types, to make phytogeographical comparison of the forest with other similar forests in the country and to assess the status of the vegetation and to make some recommendations on the management and conservation of the forest.
Sci. Technol. Arts Res. J., April-June 2013, 2(2): 58-69

\section{MATERIALS AND METHODS}

\section{The Study Area}

Location: Komto Forest is administratively located in Wayu Tuka District of East Wollega Zone in Oromia National Regional State, $330 \mathrm{~km}$ west of Addis Ababa along Addis Ababa-Gimbi road and 12 $\mathrm{km}$ east of Nekemte, the capital town of East Wollega Administrative Zone. It covers an area of about 500 ha. The forest lies in the range of latitudes $9^{0} 05.10^{\prime}$ to $9^{0} 06.35^{\prime} \mathrm{N}$ and longitude $036^{\circ} 36.47^{\prime}$ and $036^{\circ} 38.10^{\prime} \mathrm{E}$ (Figure 1).

The rainfall and temperature data for this study were collected from the nearest Meteorological Station, Nekemte, which is about $12 \mathrm{~km}$ away from the capital of Wayu Tuka District. The data were collected from 1998-2007 by National Meteorological Service Agency (NMSA, 2009). Climate diagram was computed by using $R$ for window version 2.10.1 statistical package (RDevelopment Core Team, 2007). The area falls within the southwestern and western unimodal rainfall region of Ethiopia. Generally, the study area (Komto Forest) is humid and moderately hot. The mean annual temperature is about $18.8^{\circ} \mathrm{C}$ and the mean minimum and maximum temperatures are $12.2^{\circ} \mathrm{C}$ and $27.9^{\circ} \mathrm{C}$ respectively (Figure 2). The mean annual rainfall of the study area is $2067 \mathrm{~mm}$. The rainfall pattern is unimodal, with little or no rainfall in January and February, gradually increasing to peak period between May and October, and decreasing in November and December (Figure 2).

The vegetation of the study area (eastern highlands of Wollega) is broad-leaved and evergreen moist forests with important tree species in the forests including Pouteria adolfi-friederici, Syzygium guineense ssp. afromontanum, Apodytes dimidiata, Prunus africana, Albizia gummifera, Albizia schimperiana, Croton macrostachyus, Cassipourea malosana, Ekebergia capensis, Euphorbia ampliphylla, Ficus sur and shrubs e.g. Maesa lanceolata, Teclea nobilis, and Bersama abyssinica (Demel Teketay, 2002).

Komto Forest also hosts various species of wild animals including mammals, birds, reptiles and amphibians. Some of the common mammals are spotted hyena, abyssinian black and white colobus monkey, common jackal, blue monkey, bushbuck, common duicker, aardvark, olive baboon, hare, vervet monkey, crested porcupine, etc. However, the wildlife populations of these animals are under severe threat due to deforestation and habitat fragmentation mainly because of human encroachment. 
Fekadu Gurmessa et al.,

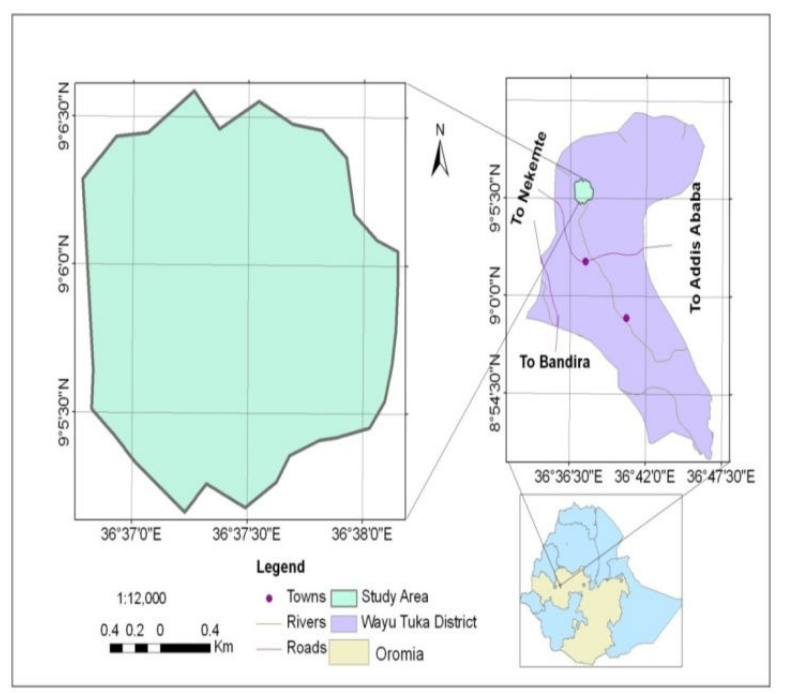

Figure 1: Location Map of Wayu Tuka District and Study area.

\section{Method}

Reconnaissance survey was made during the last week of September, 2009 in order to obtain an impression of the site conditions and to select sampling sites.

\section{Sampling Design}

Systematic sampling following Kent and Coker (1992) and Muller-Dombois and Ellenberg (1974) was used for the study. Sampling sites were arranged along transects in eight $(E, N E, N, N W, W$, SW, S, SE) directions from the peak of the mountain Komto down to the base and to the surrounding plain and a transect of one quadrat at the top of the mountain. Each of the eight transects contain different number of $20 \mathrm{~m} \times 20 \mathrm{~m}\left(400 \mathrm{~m}^{2}\right)$ plots for woody species at a distance of $200 \mathrm{~m}$ from each other depending on the length of the transect. A total of 53 quadrats were laid for vegetation data collection.. In addition, five $1 \mathrm{~m} \times 1 \mathrm{~m}$ sub plots, one at each corner and one at the center of the main plot were also laid to sample herbaceous plants.

\section{Vegetation Data Collection}

Data collection was conducted from October 15 to November 25, 2009. A complete list of trees, shrubs and herbs including vascular epiphytes was made from the systematically selected plots along each transect. Species occurring within $10 \mathrm{~m}$ distance from the plots boundaries were also recorded as present for floristic composition. Vernacular names of species were recorded during field work. Specimens of all vascular plant taxa were collected, pressed, dried and brought to the National Herbarium (ETH), Addis Ababa University for identification and storage. The nomenclature of the taxa follows Flora of Ethiopia and Eritrea (FEE).
Sci. Technol. Arts Res. J., April-June 2013, 2(2): 58-69

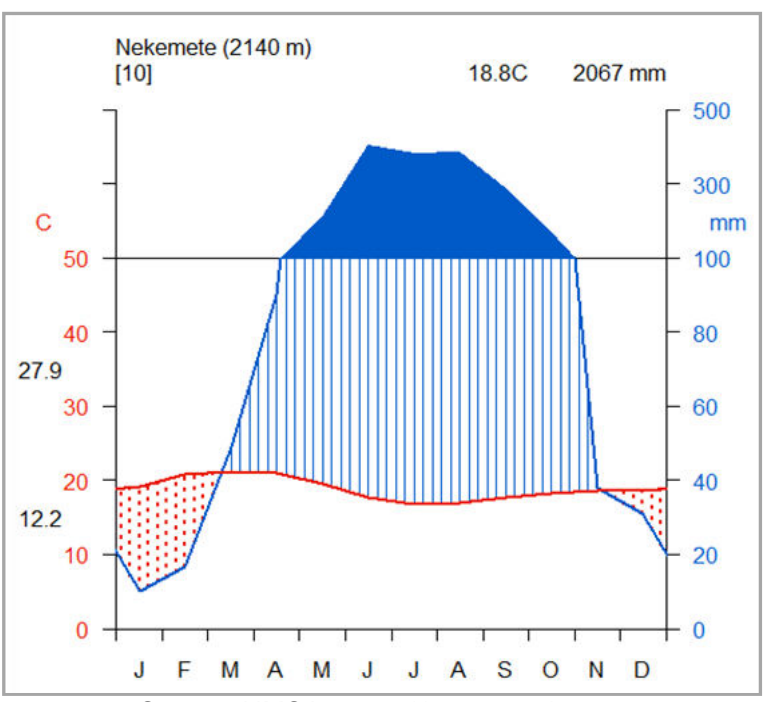

Source: NMSA, 2009 (1998-2007).

Figure 2: Climatic diagram of Nekemte Town.

The presence-absence and cover abundance data, defined here as the proportion of area in a quadrat covered by every species recorded and gathered from each quadrat were later converted to cover abundance values using the modified 1-9 Braun-Blanquet scale (vander Maarel, 1979) as follows.

1: Rare, generally one individual;

2: Occasional, with less than $5 \%$ cover of the total;

3: Abundant, with less than $5 \%$ cover of the total;

4: Very abundant, with less than $5 \%$ cover of the total;

5: $5-12 \%$ cover of the total area;

6: $12-25 \%$ cover of the total area;

7: $25-50 \%$ cover of the total area;

8: $50-75 \%$ cover of the total area;

9: $75-100 \%$ cover of the total area;

\section{Data Analysis}

\section{Multivariate Analysis of Vegetation Data}

Classification by means of hierarchical cluster analysis is the most common multivariate technique to analyze community data. Cluster analysis helps to group a set of observations (here plots or vegetation samples) together based on their attributes or floristic similarities (Kent and Coker, 1992; McCune and Grace, 2002). Accordingly, a hierarchical cluster analysis was performed using PC-ORD for windows version 5.0 (McCune and Mefford, 1999) to classify the vegetation into plant community types based on abundance data of the species in each quadrat. The Relative Euclidean Distance (RED) measures using Ward's method were used in the current study. The data matrix contained 53 plots and 114 species collected from the sample plots. The Euclidean Distance was used because it eliminates the differences in total abundance among sample units and the Ward's 
Fekadu Gurmessa et al.,

method was used because it minimizes the total within group mean of squares or residual sum of squares (van Tongeren, 1995; McCune and Grace, 2002).

The clusters were further tested for the hypothesis of no difference between the groups using the multi-response permutation procedure (MRPP). Dufren and Legender's (1997) method of calculating species indicator values was used to detect the values of different species. Indicator species are defined as the most characteristic species of each group found mostly in a single group of the typology and present in the majority of the sites belonging to that group (Dufren and Legender, 1997). Indicator values are measures of the fidelity of the occurrence of a species in a particular group (McCune and Mefford, 1999) and its value ranges from zero (no indication) to 100 (perfect indication). Indicator values were also tested for statistical significance using Monte Carlo technique. The clusters were designated as plant community types and given names after one or two dominant or characteristic species. A species is considered as an indicator of the group when its indicator value is significantly higher at $p<0.05$.

\section{Diversity and Similarity Indices}

Biological diversity can be quantified in different ways. Shannon-Wiener diversity index, species richness and Shannon's evenness were computed to describe species diversity of the plant community types in the vegetation. Shannon - Wiener diversity index is the most popular measure of species diversity because it accounts both for species richness and evenness, and it is not affected by sample size (Kent and Coker, 1992; Krebs, 1999). Shannon-Wiener diversity index was calculated as follows.

$$
H^{\prime}=-\sum_{i=1}^{s} p_{i} \ln p_{i}
$$

Where,

$\mathbf{H}^{\prime}$ = Shannon diversity index,

$\mathbf{S}=$ the number of species,

$\mathbf{P}_{\mathbf{i}}=$ the proportion of individuals or the abundance of the $i^{\text {th }}$ species expressed as a proportion of total cover and

In $=$ logbase

Evenness (Equitability) J=H'/H'max,

Where,

J=Evenness,

$\mathbf{H}^{\prime}=$ Shannon-Wiener diversity index and

$H^{\prime} \max =\ln s$ where $s$ is the number of species.

The higher the value of $\mathrm{J}$, the more even the species is in their distribution within the community or the quadrats. Similarly, the higher the value of $\mathrm{H}^{\prime}$, the more diverse the community or the quadrat are.
Sci. Technol. Arts Res. J., April-June 2013, 2(2): 58-69

Sorensen's similarity index was used to determine the pattern of species turnover among successive communities and to compare the forest with other similar forests in the country. It is described using the following formula (Kent and Coker, 1992).

$S_{s}=2 a /(2 a+b+c)$,

Where,

$\mathbf{S}_{\mathbf{s}}=$ Sorensen's similarity coefficient

$\mathbf{a}=$ Number of species common to both samples;

$\mathbf{b}=$ Number of species in sample 1 ;

c $=$ Number of species in sample 2

\section{RESULT}

\section{Plant Species Composition of Komto Forest}

A total of 180 plant species belonging to 151 genera and 66 families were recorded and identified from Komto Forest. Out of these, 42 species $(23.33 \%)$ were trees, 43 species $(23.88 \%)$ were shrubs, 62 species $(34.44 \%)$ were herbs, 11 $(6.11 \%)$ grasses and sedges, 14 species $(7.77 \%)$ were lianas, 7 species $(3.88 \%)$ were ferns and 1 $(0.55 \%)$ species was a woody hemi parasite (Figure 3). Of all the families, Fabaceae and Asteraceae were the most dominant with each contributing 17 species $(9.44 \%)$ to the total and followed by Lamiaceae, Malvaceae and Poaceae with 10 species (5.55\%), 9 species (5\%), and $9(5 \%)$, respectively. Euphorbiaceae with $8(4.44 \%)$ species and Acanthaceae and Celastraceae each with 6 $(3.33 \%)$ species were also very important families in terms of species richness. Thirty six families consisted of only 1 species each. The number of species and genera for the rest of the families are given in Table 1. In addition, of all the species collected, $89.44 \%$ were dicots, $6.67 \%$ were monocots and $3.89 \%$ were ferns (Figure 3). No Gymnosperm was identified in the Forest. The large percentage of dicots is due to their evolutionary advancement.

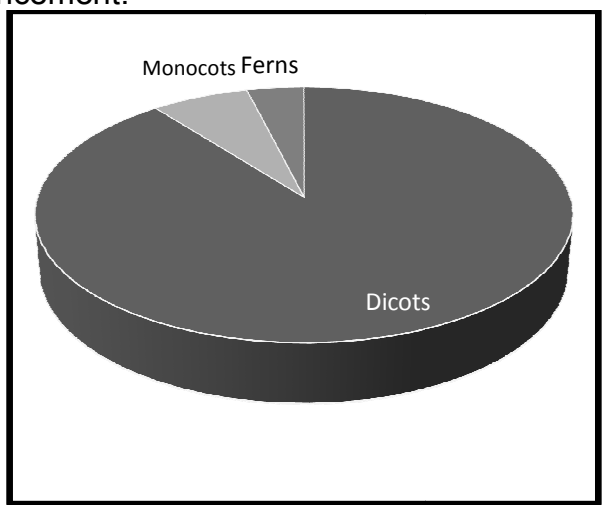

Figure 3: Percentage contribution of Dicots, Monocots and Ferns. 
Fekadu Gurmessa et al.,

Table 1. Families with their corresponding number of genera and species.

\begin{tabular}{lcccc}
\hline & \multicolumn{2}{c}{ Genera } & \multicolumn{2}{c}{ Species } \\
\cline { 2 - 5 } Family & No & $\%$ & No & $\%$ \\
\hline Fabaceae & 14 & 9.27 & 17 & 9.44 \\
Asteraceae & 11 & 7.28 & 17 & 9.44 \\
Poaceae & 8 & 5.29 & 9 & 5.00 \\
Lamiaceae & 10 & 6.62 & 10 & 5.55 \\
Malvaceae & 5 & 3.31 & 9 & 5.00 \\
Euphorbiaceae & 6 & 3.97 & 8 & 4.44 \\
Acanthaceae & 5 & 3.31 & 6 & 3.33 \\
Celastraceae & 2 & 1.32 & 6 & 3.33 \\
Urticaceae & 3 & 1.98 & 4 & 2.22 \\
Asclepiadaceae & 4 & 2.65 & 4 & 2.22 \\
Cucurbitaceae & 5 & 3.31 & 5 & 2.77 \\
Oleaceae & 3 & 1.98 & 4 & 2.22 \\
Rosaceae & 3 & 1.98 & 4 & 2.22 \\
Rubiaceae & 4 & 2.65 & 4 & 2.22 \\
Solanaceae & 2 & 1.32 & 4 & 2.22 \\
Rhamnaceae & 3 & 1.98 & 3 & 1.66 \\
Rutaceae & 3 & 1.98 & 3 & 1.66 \\
Scrophulariaceae & 3 & 1.98 & 3 & 1.66 \\
Tiliaceae & 3 & 1.98 & 3 & 1.66 \\
Amaranthaceae & 2 & 1.32 & 2 & 1.11 \\
Balsaminaceae & 1 & 0.66 & 2 & 1.11 \\
Cyperaceae & 2 & 1.32 & 2 & 1.11 \\
Dracaenaceae & 1 & 0.66 & 2 & 1.11 \\
Loganiaceae & 2 & 1.32 & 2 & 1.11 \\
Meliaceae & 2 & 1.32 & 2 & 1.11 \\
Moraceae & 1 & 0.66 & 2 & 1.11 \\
Myrsinaceae & 2 & 1.32 & 2 & 1.11 \\
Polygonaceae & 2 & 1.32 & 2 & 1.11 \\
Pteridaceae & 2 & 1.32 & 2 & 1.11 \\
Ranunculaceae & 2 & 1.32 & 2 & 1.11 \\
Others & 36 & 23.18 & 36 & 19.44 \\
\hline Total & $\mathbf{1 5 1}$ & $\mathbf{1 8 0}$ & $\mathbf{1 0 0}$ \\
\hline & & &
\end{tabular}

Sci. Technol. Arts Res. J., April-June 2013, 2(2): 58-69

Analysis of the habit or growth forms of species recorded from Komto Forest was performed (Figure $4)$. Accordingly, the highest proportion $(34.44 \%)$ was herbs. This was followed by shrubs $(23.88 \%)$ and trees (23.33\%). In addition, lianas, grasses and sedges and ferns comprised of $8.09 \%, 6.11 \%$ and $4.04 \%$ of the total, respectively (Figure 4). List of plant species not yet recorded from wollega floristic region is given in Table 2. Komto Forest also contain a number of endemic plant species to Ethiopia (Table 3).

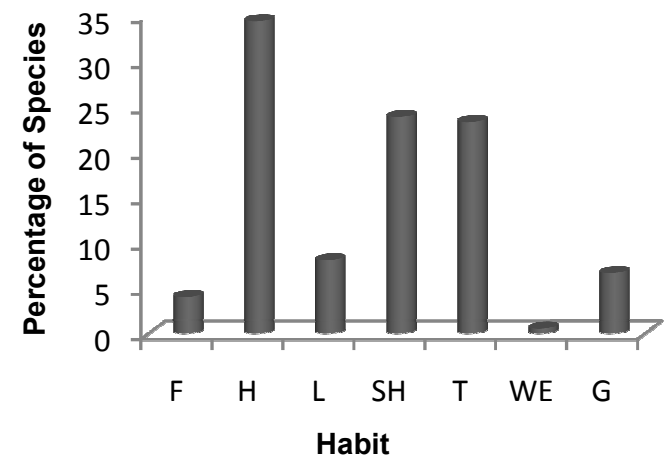

(F=Fern, H=Herb, L=Liana, $\mathrm{SH}=$ Shrub, $\mathrm{T}=$ Tree, $\mathrm{G}=$ Grasses and
Sedges and WE=Woody Epiphyte/Hemiparasite)

Figure 4: Habit of Plants in Komto Forest

\section{Vegetation Classification}

Four plant communities were derived from the hierarchical cluster analysis (Figure 5). The test statistics $T$ value for the four groups were -18.005 $(p<0.001)$, highly significant, and the agreement statistics $A$ was 0.099 . A list of the community types along with the indicator values of the species is given in Table 4. Bold values indicate significant indicator value $(p<0.05)$ in each group.

Community names were given after one or two species that had higher indicator values. The latter distinguished the community by their high relative abundance and relative frequency. In all observed plant communities, species with higher indicator values are those that were easily observed repeating themselves in associations. Thus the identified groups are more or less coinciding with the natural associations that anyone can observe while crossing through the forest. The following is the description of the community types identified from the forest. 
Table 2: Species not reported from Wollega floristic region (WG) on Flora of Ethiopia and Eritrea.

\begin{tabular}{|c|c|c|c|c|}
\hline No. & Species Name & Family & $\begin{array}{l}\text { Growth } \\
\text { form }\end{array}$ & $\begin{array}{l}\text { Vernacular Name } \\
\text { (Afaan Oromoo) }\end{array}$ \\
\hline 1 & Abutilon mauritianum & Malvaceae & $\mathrm{SH}$ & \\
\hline 2 & Achyrospermum schimperi & Lamiaceae & $\mathrm{SH}$ & \\
\hline 3 & Andropogon abyssinicus & Poaceae & $\mathrm{G}$ & Baallammii \\
\hline 4 & Ceropegia sobolifera & Asclepiadaceae & $\mathrm{L}$ & \\
\hline 5 & Conium maculatum & Apiaceae & $\mathrm{H}$ & \\
\hline 6 & Crepis foetida & Asteraceae & $\mathrm{H}$ & \\
\hline 7 & Crotalaria rosenii & Fabaceae & $\mathrm{SH}$ & \\
\hline 8 & Cynodon dactylon & Poaceae & $\mathrm{G}$ & Coqorsa \\
\hline 9 & Cynoglossum amplifolium & Boraginaceae & $\mathrm{H}$ & \\
\hline 10 & Cyperus distans & Cyperaceae & G & Qunnii \\
\hline 11 & Digitaria velutina & Poaceae & G & Daggoo \\
\hline 12 & Dryopteris inaequalis & Dryopteridaceae & $\mathrm{H}$ & \\
\hline 13 & Euphorbia ampliphylla & Euphorbiaceae & $\mathrm{T}$ & Adaamii \\
\hline 14 & Impatiens tinctoria ssp. abyssinica & Balsaminaceae & $\mathrm{H}$ & Hansoosillaa Gogorrii \\
\hline 15 & Isoglossa somalensis & Acanthaceae & $\mathrm{H}$ & \\
\hline 16 & Kalanchoe densiflora & Crassulaceae & $\mathrm{H}$ & \\
\hline 17 & Lagenaria abyssinica & Cucurbitaceae & $\mathrm{H}$ & Buqqee Seexanaa \\
\hline 18 & Leptadenia arborea & Asclepiadaceae & $\mathrm{L}$ & \\
\hline 19 & Maytenus addat & Celasteraceae & $\mathrm{T}$ & Kombosha \\
\hline 20 & Olea capensis ssp. macrocarpa & Oleaceae & $\mathrm{T}$ & Gagamaa \\
\hline 21 & Panicum hochstetteri & Poaceae & G & \\
\hline 22 & Panicum nervatum & Poaceae & G & \\
\hline 23 & Pteris catoptera & Pteridaceae & Fern & \\
\hline 24 & Solanecio gigas & Asteraceae & $\mathrm{SH}$ & Jilma Jaldeessaa \\
\hline 25 & Solanum incanum & Solanaceae & $\mathrm{SH}$ & Hiddii Loonii \\
\hline 26 & Solanum marginatum & Solanaceae & $\mathrm{SH}$ & Hiddii Hongorcaa \\
\hline 27 & Tagetes minuta & Asteraceae & $\mathrm{H}$ & \\
\hline 28 & Tagetes patula & Asteraceae & $\mathrm{H}$ & \\
\hline 29 & Tiliacora troupinii & Menispermaceae & $\mathrm{L}$ & Hidda Liqixii \\
\hline 30 & Trifolium semiplosum & Fabaceae & $\mathrm{H}$ & Siddisa \\
\hline 31 & Urtica simensis & Urticaceae & $\mathrm{H}$ & Gurgubbee \\
\hline
\end{tabular}

( $\mathrm{S}=$ Shrub, $\mathrm{G}=$ Grass \& Sedge, $\mathrm{H}=\mathrm{Herb}, \mathrm{L}=$ Liana, $\mathrm{T}=$ Tree)

Table 3: Endemic species in Komto Forest

\begin{tabular}{llll}
\hline No. & Scientific Name & Family & Status \\
\hline 1 & Acalypha marissima & Euphorbiaceae & EN \\
2 & Ceropegia sobolifera & Asclepiadaceae & CR \\
3 & Crassocephalum macropappum & Asteraceae & LC \\
4 & Crotalaria rosenii & Fabaceae & NT \\
5 & Echinops longisetus & Asteraceae & LC \\
6 & Erythrina brucei & Fabaceae & LC \\
7 & Justicia diclipteroides ssp. aethiopica & Acanthaceae & NT \\
8 & Lippia adoensis & Verbenaceae & LC \\
9 & Maytenus addat & Celestraceae & NT \\
10 & Millettia ferruginea ssp. ferruginea & Fabaceae & LC \\
11 & Phragmanthera macrosolen & Loranthaceae & LC \\
12 & Rhus glutinosa & Anacardiaceae & LC \\
13 & Satureja paradoxa & Lamiaceae & NT \\
14 & Solanecio gigas & Asteraceae & LC \\
15 & Tiliacora troupinii & Menispermaceae & VU \\
16 & Urtica simensis & Urticaceae & LC \\
17 & Vepris dainellii & Rutaceae & NT \\
18 & Vernonia leopoldi & Asteraceae & LC \\
\hline
\end{tabular}

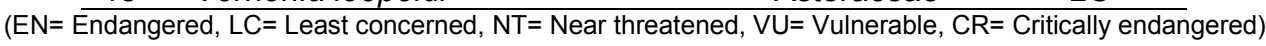




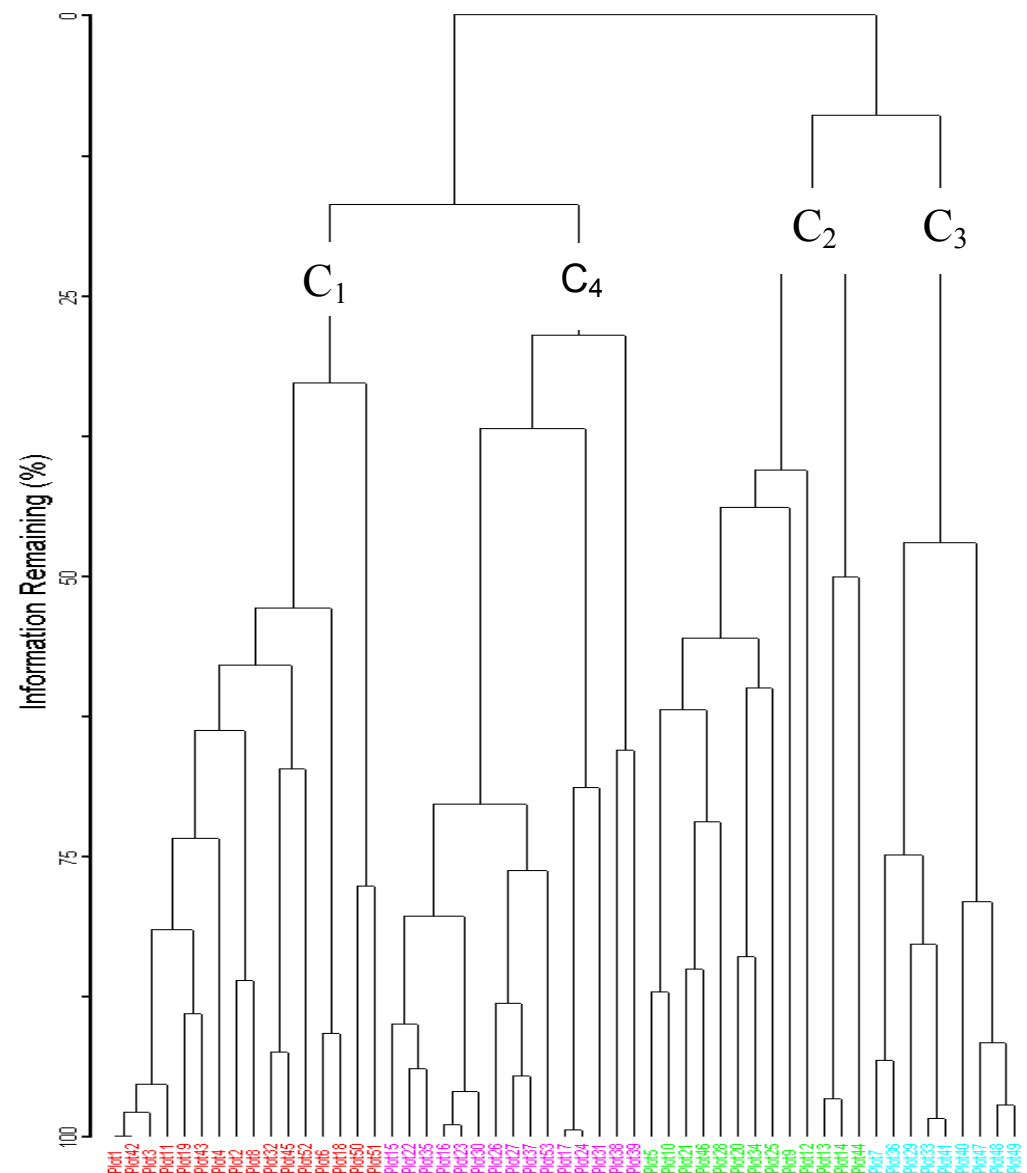

$\mathbf{C}_{1}$ : Plots 1, 2, 3, 4, 6, 8, 11, 18, 19, 32, 42, 43, 45, 50, 51 and 52.

$\mathbf{C}_{2}$ : Plots 5, 9, 10, 12, 13, 14, 20, 21, 25, 28, 34, 44 and 46.

$\mathrm{C}_{3}$ : Plots $7,29,33,36,40,41,47,48$ and 49.

$\mathbf{C}_{4}$ : Plots 15, 16, 17, 22, 23, 24, 26, 27, 30, 31, 35, 37, 38, 39 and 53.

Figure 5: Dendrogram of the vegetation data obtained from hierarchical cluster analysis of Komto Forest using Ward's method and Euclidean distance. The level of grouping was based on about $20 \%$ Information remaining. $\left(C_{1}=\right.$ Community type $1, C_{2}=$ Community type $2, C_{3}=$ Community type 3 and $\mathrm{C}_{4}=$ Community type 4 )

\section{Achyrospermum Macrostachyus Type \\ Schimperi- Croton}

This community type was represented by 16 quadrats and 89 species. The community had five indicator species (Achyrospermum schimperi, Croton macrostachyus, Rytigynia neglecta, Vernonia amygdalina and Hippocratea goetzei) with significant indicator values (Table 4). The altitudinal range of this community was from 2167-2357 m a.s.l. Woody species (trees, shrub and lianas) associated with this community are Clausena anisata, Erythrococca trichogyne, Bersama abyssinica, Vernonia auriculifera, Maesa lanceolata, Rubus apetalus, Canthium oligocarpum, Allophylus abyssinicus, Vepris dainellii, Cassiporea malosana, Hagenia abyssinica, Millettia ferruginia ssp. ferruginia, Combretum paniculatum, Leucas martinicensis, and Ritchiea albersii.
Herbs such as Hypoestes forskaolii, Impatiens hochstetteri, Kalanchoe densiflora, Acalypha marissima, Drymaria cordata, Eriosema scioanum, Cynoglossum amplifolium, Tagetes minuta, and Digitaria velutina are the dominant in the herb layer of this community.

\section{Solanecio Gigas-Ficus Sur y Type}

This community comprised of 13 quadrats and 71 species. The community is distributed between the altitudinal ranges of 2184 and $2380 \mathrm{~m}$ a.s.l. This community has four indicator species (Solanecio gigas, Ficus sur, Pouteria adolfi-friederici and Dracaena steudneri) (Table 4). Ficus sur and Pouteria adolfi-friederici are the emergent trees of this community type. Other trees, shrubs and lianas associated with this community include Albizia schimperiana, Albizia gummifera, Allophylus 
Fekadu Gurmessa et al.,

abyssinicus, Bersama abyssinica, Brucea antidysenterica, Cassipourea malosana, Celtis africana, Maesa lanceolata, Olea capensis ssp. macrocarpa, Olea welwitschii, Psychotria orophila, Rubus steudneri, Rytigynia neglecta, Solanum anguivi, Abutilon martinianum, Acanthus eminens and Clematis simensis.

The herb layer is composed of Achyranthes aspera, Cyathula uncinulata, Achyrospermum schimperi, Desmodium repandum, Girardinia diversifolia, Mimulopsis solmsii, Bidens ghedoensis, Momordica foetida, Pteris catoptera, Vigna vexillata and Pteridium aquilinum.

\section{Justicia schimperiana-Acanthus Eminens Type}

This community type was distributed and is situated at altitudinal ranges from 2180 to 2313 m.a.s.l. The community is comprised of 9 quadrats and 62 species. The indicator species characterizing this community are Justicia schimperiana, Acanthus eminens, Erythrococca trichogyne and Landolphia buchanani (Table 4). The other woody species (trees, shrubs and lianas) associated with this community include Pittosporum viridiflorum, Urera hypselodendron, Syzygium guineense ssp. afromontanum, Teclea nobilis, Bersama abyssinica, Brucea antidysenterica, Calpurnia aurea, Clausena anisata, Clematis simensis, Cyphostemma adenocaule, Embelia schimperi, Dregia schimperi, Ocimum lamifolium, Hippocratea africana, Crotalaria mildbraedii, Vernonia auriculifera, Croton macrostachyus, Flacourtia indica, Macaranga capensis, Maytenus gracilipes, Maytenus addat, Chionanthus mildbraedii and Vepris dainellii.
Sci. Technol. Arts Res. J., April-June 2013, 2(2): 58-69

Herbs such as Cyathula uncinulata, Achyrospermum schimperi, Achyranthes aspera, Hypoestes forskaolii, Justicia declipteroides ssp aethiopica and Tragia brevipes are also common in this community.

\section{Periplocca Linearifolia-Dracaena Afromontana Type}

This community is dominated by the woody climber, i.e. Periplocca linearifolia. The other indicator species with significant indicator values are Dracaena afromontana, Cyperus distans, Hibiscus macranthus, Euphorbia ampliphylla and Solenostemon autranii (Table 4). This community type lies along the altitudinal range of 2256 to 2482 . Only three quadrats in this community are below $2325 \mathrm{~m}$ a.s.l. indicating that this community occupied the higher altitude of the study area. Fifteen quadrats and 79 species were encountered. Along with the above indicator species, Apodytes dimdiata, Abutilon longicuspe, Dombeya torrida, Prunus africana, Maytenus undata, Ekebergia capensis, Asparagus africanus, Allophylus abyssinicus, Syzygium guineense ssp. afromontanum, Rubus steudneri, Vepris dainellii, Clerodendrum myricoides, Sparmannia ricinocarpa, Schefflera abyssinica, Rhus glutinosa and Premna schimperi are common woody species of this community.

Solenostemon autranii, Panicum hochstetteri, Setaria megaphylla, Pteridium aquilinum, Zhneria scabra, and Isoglossa somalensis are the dominant herbs of the community.

Table 4: Indicator Values (\% of perfect Indication) of each species for each of the four groups and the Monte Carlo test $\left(\mathrm{P}^{*}\right)$ of the significance observed for each species.

\begin{tabular}{|c|c|c|c|c|c|}
\hline \multirow[b]{2}{*}{ Name of Species } & \multicolumn{4}{|c|}{ Communities } & \multirow[b]{2}{*}{$\mathbf{P}^{*}$} \\
\hline & 1 & 2 & 3 & 4 & \\
\hline Achyrospermum schimperi & 41 & 11 & 18 & 0 & 0.0022 \\
\hline Croton macrostachyus & 40 & 10 & 24 & 7 & 0.0050 \\
\hline Rytigynia neglecta & 40 & 20 & 9 & 4 & 0.0066 \\
\hline Vernonia amygdalina & 30 & 3 & 0 & 2 & 0.0176 \\
\hline Hippocratea goetzei & 25 & 0 & 0 & 0 & 0.0256 \\
\hline Solanecio gigas & 4 & 68 & 3 & 2 & 0.0002 \\
\hline Ficus sur & 2 & 56 & 1 & 2 & 0.0004 \\
\hline Pouteria adolfi-friederici & 0 & 41 & 9 & 6 & 0.0128 \\
\hline Dracaena steudneri & 1 & 28 & 3 & 3 & 0.0262 \\
\hline Justicia schimperiana & 10 & 10 & 54 & 8 & 0.0002 \\
\hline Acanthus eminens & 7 & 20 & 48 & 15 & 0.0002 \\
\hline Erythroccoca trichogyne & 25 & 4 & 38 & 2 & 0.0106 \\
\hline Landolphia buchananii & 1 & 0 & 32 & 3 & 0.0064 \\
\hline Periploca linearifolia & 4 & 1 & 0 & 41 & 0.0024 \\
\hline Dracaena afromontana & 0 & 1 & 2 & 37 & 0.0034 \\
\hline Cyperus distans & 0 & 0 & 0 & 32 & 0.0048 \\
\hline Hibiscus macranthus & 0 & 0 & 0 & 27 & 0.0178 \\
\hline Euphorbia ampliphylla & 0 & 0 & 1 & 25 & 0.0252 \\
\hline Solenostemon autranii & 0 & 0 & 0 & 20 & 0.0408 \\
\hline
\end{tabular}


Fekadu Gurmessa et al.,

Species Diversity, Evenness and Richness of the Plant Communities

Table 5 shows the Hanon Wiener diversity index of the four community types and Table 6 indicates
Sci. Technol. Arts Res. J., April-June 2013, 2(2): 58-69

the Sorensen similarity coefficient among the four community types.

Table 5: Shanon Wiener Diversity Index.

\begin{tabular}{cccccc}
\hline Communities & $\begin{array}{c}\text { Average } \\
\text { altitude } \\
\text { (m a.s.I) }\end{array}$ & $\begin{array}{c}\text { Species } \\
\text { Richness }\end{array}$ & $\begin{array}{c}\text { Diversity } \\
\text { Index (H') }\end{array}$ & $\begin{array}{c}\text { H'max }^{\prime} \text { (Ln S) } \\
\text { I }\end{array}$ & $\begin{array}{c}\text { Evenness } \\
\text { (H'/H'max) }\end{array}$ \\
\hline II & 2274.4 & 89 & 3.830 & 4.49 & 0.851 \\
III & 2299.3 & 71 & 3.606 & 4.26 & 0.846 \\
IV & 2244 & 62 & 3.354 & 4.13 & 0.813 \\
\hline
\end{tabular}

Table 6: Sorensen similarity coefficient among community types.

\begin{tabular}{ccccc}
\hline Communities & $\mathbf{1}$ & $\mathbf{2}$ & $\mathbf{3}$ & $\mathbf{4}$ \\
\hline $\mathbf{1}$ & & & & \\
$\mathbf{2}$ & 0.71 & & & \\
$\mathbf{3}$ & 0.75 & $\mathbf{0 . 7 6 7}$ & & \\
$\mathbf{4}$ & 0.699 & 0.733 & $\mathbf{0 . 7 6 6}$ & \\
\hline
\end{tabular}

\section{Phytogeographical Comparison}

Many authors have studied the dry afromontane and moist afromontane forests in the country. Although the direct comparison of the species diversity with other forests is not feasible due to differences in size of forests, survey methods, and objective of the study (Tadesse Woldemariam, 2003), the overall species richness of the forest can give more or less a general impression of their diversity and phytogeographical similarity. In this regard, Komto Forest was compared with other 10 afromontane forests in the country to know the similarity of species in the forests and indicate to which forest type Komto Forest is related. Table 7 gives the findings of this comparison. Ninty nine woody species (trees, shrubs and lianas) were used for similarity comparisons. The similarity index used for this comparison was Sorensen's Similarity index.

Accordingly, Komto Forest shared significant number of species with Alata Bolale, Gendo (Gura Tirigni), Yayu, Jima, Masha Anderacha and Southwestern Ethiopian forest in decreasing order. Lower number of species was shared between Komto and Belete, Harenna, Menagesha Suba and Jibat forests.

Table 7: Phytogeographical Comparison of Komto forest with other 10 forests in Ethiopia.

\begin{tabular}{|c|c|c|c|c|c|c|c|c|}
\hline No. & Forest & $\begin{array}{c}\text { Altitudinal } \\
\text { range } \\
\text { (m a.s.l.) }\end{array}$ & $\begin{array}{c}\text { No. of } \\
\text { Spp. in } \\
\text { comparison }\end{array}$ & $\mathbf{a}$ & b & c & $\begin{array}{l}\text { Sc } \\
(\%)\end{array}$ & References \\
\hline 1 & Menagesha suba & $2300-3000$ & 48 & 29 & 70 & 19 & 39 & Tamrat Bekele, 1993 \\
\hline 2 & Jibat & $2000-2950$ & 48 & 29 & 70 & 19 & 39 & Tamrat Bekele, 1993 \\
\hline 3 & Harenna & $2200-3300$ & 85 & 40 & 59 & 45 & 43 & Lissanework Nigatu, 1987 \\
\hline 4 & Belete & $1850-2250$ & 79 & 44 & 55 & 35 & 49 & $\begin{array}{l}\text { Kitessa Hundera and } \\
\text { Tsegaye Gadissa, } 2008\end{array}$ \\
\hline 5 & Masha-Anderacha & $1250-2700$ & 107 & 54 & 45 & 53 & 52 & $\begin{array}{l}\text { Kumlachew Yeshitila and } \\
\text { Taye Bekele, } 2003\end{array}$ \\
\hline 6 & $\begin{array}{l}\text { Southwestern } \\
\text { Ethiopian forest }\end{array}$ & $1050-2600$ & 100 & 52 & 47 & 48 & 52 & Kumlachew Yeshitila, 1997 \\
\hline 7 & Jima & $2166-2470$ & 90 & 51 & 48 & 39 & 54 & Fufa Kenea, 2008 \\
\hline 8 & Yayu & $1200-2000$ & 92 & 56 & 43 & 36 & 58 & Tadesse Woldemariam, 2003 \\
\hline 9 & Gendo & $2183-2300$ & 90 & 59 & 40 & 31 & 60 & Teshome Gemechu, 2009 \\
\hline 10 & Alata-Bolale & $2061-2360$ & 98 & 66 & 33 & 32 & 67 & Woldeyohannes Enkossa, 2008 \\
\hline
\end{tabular}


Fekadu Gurmessa et al.,

\section{DISCUSSION}

\section{Floristic Description}

Out of the 180 plant species collected from Komto Forest, 31 were new records for Wollega (WG) floristic region in the flora of Ethiopia and Eritrea. These species belong to 28 genera and 21 families with $12(38.71 \%)$ herbs, $6(19.35)$ grasses and sedges, $6(19.35 \%)$ shrubs, $3(9.67 \%)$ lianas and $3(9.67 \%)$ tree species and 1 (3.22) fern (no gymnosperm species was recorded in the natural vegetation of Komto Forest). In addition, Komto Forest contains a number of flowering plant species that are endemic to Ethiopia. Endemic plant species of Ethiopia and their level of threat have been given in Ensermu Kelbessa et al. (1992) and Vivero et al. (2005). Accordingly, 18 (10\%) endemic species, some of which are in the IUCN Red Data List, were identified in Komto Forest. Based on available literature (Vivero et al., 2004; Vivero et al., 2005; Vivero et al., 2006), the endemic species and the level of their threat are given in Table 3.

Komto Forest also contained 11 (45.83\%) out of 24 major commercial indigenous tree species reported by EFAP (1994) and Million Bekele and Leykun Berhanu (2001). These tree species include Albizia gummifera, Albizia schimperiana, Pouteria adolfi-friederici, Apodytes dimidiata, Celtis africana, Croton macrostachyus, Ekebergia capensis, Hagenia abyssinica, Olea welwitschii, Prunus africana and Syzygium guineense ssp. afromontanum.

\section{Species Diversity, Evenness and Richness of the Plant Communities}

The highest species richness was observed in community one while community four was with maximum diversity. The possible reason for high species richness of community 1 may be altitudinal factor because intermediate altitude could be associated with optimal conditions of environmental factors that favor vegetation growth. Community four was with the highest diversity because its species are evenly distributed although relatively fewer species were recorded. Community type 3 exhibited the least species richness and diversity. This is due to the vicinity of this plant community to human settlements (the community lies along the margin of the forest and easily accessible) has subjected it to high anthropogenic influences such as selective removal of economically important trees, grazing by live stock. Other environmental factors such as aspect, slope, etc could also contribute for the low species richness and diversity. For example, Livestocks were observed in the forest margin during field study.
Sci. Technol. Arts Res. J., April-June 2013, 2(2): 58-69

\section{Similarity among Plant Communities}

Sorenson's similarity coefficient was used to determine the similarities among plant communities. Accordingly, Communities 2 and 3 had the highest similarity ratio. This could be associated to slope, aspect, the anthropogenic and other environmental factors such as soil type and properties which were not considered in this study. The least similarity was exhibited by communities 1 and 4 may be due to the variation in altitude, slope, aspect and other environmental factors.

Komto Forest shared more species in common with moist montane forests indicating that it is highly related to the Moist Afromontane forests in the country. The most characteristic tree species of moist Afromontane forest are found in this study area. These include Pouteria adolfi-friederici, Prunus africana, Syzygium guinneense ssp. afromontanum, Vepris dainellii, Teclea nobilis and other species which were also reported in Tadesse Woldemariam (2003) and Feyera Senbeta (2006). The altitudinal range of Komto forest is within the altitudinal range of the Moist Aformontane forests, which is from 1500 - 2500 m.a.s.l. (White, 1983; Friis, 1992; Sebsebe Demissew et al., 2004). Hence, Komto forest belongs to Moist Montane Forest Vegetation Type. The low similarity between Belete, Harenna, Menagesha Suba and Jibat forests may arise from their location (far apart from Komto Forest), altitudinal differences and climatic conditions.

\section{CONCLUSIONS}

The study has resulted in the documentation of 180 vascular plant species representing 151 genera and 66 families. Fabaceae and Asteracae were found to be the most dominant families followed by Lamiaceae, Poaceae, and Malvaceae. Euphorbiaceae, Acanthaceae and Celastaceae families had also significant contribution to the overall species composition of the Forest. Of the total species recorded, 31 were new records from Wollega (WG) floristic region in the flora of Ethiopia and Eritrea. Komto Forest was also important reservoir of endemic plants as about 18 endemic plant species some of which are in the IUCN Red Data List were identified. Hence, Komto Forest could serve the purpose of biodiversity conservation.

The vegetation of Komto Forest was grouped into four plant community types. These communities were arranged along different altitudinal range. Plant community 1 exhibited the highest species richness (89) while the highest diversity was observed for community type four. Community type three was known with the least species richness and diversity while community type two was with 
Fekadu Gurmessa et al.,

intermediate species richness and diversity. The variation in species composition and diversity among communities could be associated to different factors, such as altitude, anthropogenic impacts, soil properties, slope and aspect.

Phytogeographical comparison indicated that Komto Forest had the highest similarity with Moist Montane forests than other vegetation types implying Komto Forest is one of the Afomontane Rainforests of the country.

\section{REFERENCES}

Demel Teketay (2002). Country brief. In: States of Forests and Forestry research in Ethiopia, pp. 1-7. Demel Teketay and Tesfaye Bekele, (eds.) I-TOO working paper No. 1, Germany.

Dufrene, M. and Legender, P. (1997). Species assembledges and indicator species: the need for a flexible asymmetrical approach. Ecological Monographs 67(3):345-366.

EFAP (1994). Ethiopian Forestry Action Program, Volume III. The Challenge for Development. Ministry of Natural Resources, Addis Ababa.

EMSA (2009). Rainfall and temperature data for Nekemte town. Ethiopiaian Meteorological Services Agency. Addis Ababa, Ethiopia.

Ensermu Kelbessa and Teshome Soromessa (2008). Interfaces of regeneration, structure, diversity and uses of some plant species in Bonga Forest: A reservoir for wild coffee gene pool. SINET: Ethiopian Journal of Science 31(2): 121-134.

Ensermu Kelbessa, Sebsebe Demissew, Zerihun Woldu and Edwards, S. (1992). Some threatened Endemic Plants of Ethiopia. NAPRECA Monograph, Series 2:35-55.

Ermias Lulekal, Ensermu Kelbessa, Tamrat Bekele and Haile Yinger (2008). Plant species composition and structure of the Mana Angetu moist montane forest, Southeastern Ethiopia. Journal of East African Natural History 97(2): 165-185.

Feyera Senbeta and Demel Teketay (2003). Diversity, community types and population structure of woody plants in Kimphe Forest, a virgin Nature Reserve in Southern Ethiopia. Ethiopian Journal of Biological Sciences 2(2):169-187.

Friis I. and Sebsebe Demissew (2001). Vegetation maps of Ethiopia and Eritrea. A review of existing maps and the need for a new map for the flora of Ethiopia and Eritrea. In: Biodiversity Research in the Horn of Africa Region, pp. 399-439 (Friis, I. and Ryding, O. eds). Proceedings of the $3^{\text {rd }}$ International symposium on the Flora of Ethiopia and Eritrea at the Crlsberg Academy, Copenhagen.

Friis, I. (1992). Forest and Forest Trees of Northeast Tropical Africa: Their natural habitats and distribution pattern in Ethiopia, Djibouti and Somalia. Kew. Bull. Add. Ser 15: 396.
Sci. Technol. Arts Res. J., April-June 2013, 2(2): 58-69

Fufa Kenea (2008). Remnant vegetation and population structure of woody species of Jimma Forest, Western Ethiopia. M.Sc Thesis (Unpublished), Addis Ababa University.

Groombridge, B. (ed.) (1992). Global Biodiversity: Status of the Earth's Living Resources. World Conservation and Management Center. Chapman and Hall, London.

Hailu Sharew (1982). An ecological study of a forest in Jemjem, Sidamo. M.sc. Thesis (Unpublished) Addis Ababa University.

Institute of Biodiversity Conservation (IBC) (2008). Ethiopia: Second Country Report on the state of PGRFA to FAO. Addis Ababa, Ethiopia.

Kent, M. and Coker, P. (1992). Vegetation Description and Analysis. A practical approach. John Wiley and Sons, New York, Pp.363.

Kitessa Hundera and Tsegaye Gadissa (2008). Vegetation Compositionand structure ofthe Belete forest, Jimma zone, Southwest Ethiopia. Ethiopian Journal of Biological Sciences 7(1):1-15.

Krebs, C.J. (1999). Ecological Methodology. Second Edition. Addison-Welsey Educational Publishers, USA. $620 \mathrm{p}$.

Kumlachew Yeshitela and Tamrat Bekele (2002). Plant community analysis and ecology of Afromontane and transitional rainforest vegetation of southwestern Ethiopia. SINET. Ethiopian Journal of Sciences 25(2):155-175

Kumlachew Yeshitela and Taye Bekele (2003). The woody species composition and structure of Masha Anderacha forest, Southwestern Ethiopia. Ethiopian Journal of Biological Sciences 2 (1): 31- 48.

Kumlachew Yeshitila (1997). An ecological Study of the Afromontane vegetation of the Southwestern Ethiopia. M.Sc Thesis (Unpublished), Addis Ababa University.

Lisanework Nigatu and Mesfin Tadesse (1989). An Ecological study of the vegetation of the Harenna forest, Bale, Ethiopia. SINET. Ethiopian Journal of Sciences 12: 63-93.

McCune B. and Mefford, M.J. (1999). PC-ORD. Multivariate Analysis of Ecological Data.Window Version 5.0. MjM software, Gleneden Beach, Oregon, USA.

McCune, B. and Grace, J.B. (2002). Analysis of Ecological Communities. MjM Software Design, USA Pp. 304.

Million Bekele and Leykun Berhanu (2001). State of Forest Genetic Resources in Ethiopia. Sub-Regional workshop FAO/IPGRI/ICRAF on the conservation, management, sustainable utilization and enhancement of forest genetic resources in Sahelian and NorthSudanian Africa (Ouagadougou, Burkina Faso, 22-24 September 1998). Forest Genetic Resources Working Papers, Working Paper Forestry Department, FAO, Rome.

MOA (Ministry of Agriculture) (2000). Agroecological zonation of Ethiopia. Addis Ababa, Ethiopia. 


\section{Fekadu Gurmessa et al.,}

Muller-Dombois, D. and Ellenberg, H. (1974). Aims and Methods of Vegetation Ecology. Wiley and Sons, New York, Pp. 547.

NBSAP (2005). National Biodiversity Strategy and Action Plan. IBC, Addis Ababa.

Pimbert, M.P. and Pretty, J.N. (1995). Parks, People and Professionals. Putting "Participation" into Protected Area Management. Discussion Paper 57, UNRISD, Geneva.

R-Development Core Team (2007). A language and environment for statistical computing. R Foundation for Statistical Computing. Vienna, Austria.

Sebsebe Demissew and Friis, I. (2009). Natural vegetation of the Flora area. In: Flora of Ethiopia and Eritra. Volume 8, pp. 28-29. Hedberg, I., Friis, I. and Persson, E. (eds). The National Herbarium, Addis Ababa University, Addis Ababa.

Sebsebe Demissew, Cribb. P. and Rasmussen, F. (2004). Field Guide to Ethiopian Orchids. Kew Field guide, Royal Botanic Gardens, Kew.

Sebsebe Demissew, Mengistu Wondafrash and Yilma Delelegn (1996). Ethiopia's Natural Base. Pp. 36-53. In: Important Bird Areas of Ethiopia: A first Inventory. Ethiopian Wildlife and Natural History Society, Addis Ababa, Ethiopia.

Tadesse Woldemariam (2003). Vegetation of the Yayu forest in Southwest Ethiopia: Impacts of human use and Implications for In situ conservation of Wild Coffea arabica L. populations. Ecology and Development Series No. 10. Center for Development Research, University of Bonn, Germany.

Tamrat Bekele (1993). Studies on remnant Afromontane forests on the central plateau of Shewa, Ethiopia. Acta Phytogeographica Suecica 79: 1-58.

Teshome Gemechu (2009). Floristic composition and structure of Gendo (Gura Tirigni) moist montane forest, East Wollega zone, Oromia Region, Ethiopia. M.Sc Thesis (Unpublished), Addis Ababa University.

Vander Maarel, E. (1979). Transformation of cover abundance values in phytogeography and its effects on community similarity. Vegetatio 39:97-114

Van Tongeren, O.F.R. (1995). Cluster analysis. In: Data Analysis in Community and Landscape Ecology, pp. 174-212 (Jongman, R.H.G., Ter Braak, J.C.F. and van Tongeren, O.F.R., eds.). Cambridge University Press, Cambridge.

Vivero J.L., Ensermu Kelbessa and Sebsebe Demissew (2006). Progress on the red list of plants of Ethiopia and Eritrea: Conservation and biogeography of endemic flowering taxa. In: Taxonomy and Ecology of African Plants, their Coservation and Sustainable Use, pp.761-778 (Ghazanfar S. A. and Beentje H. J., eds). Proceedings of the $17^{\text {th }}$ AETFAT congress, Addis Ababa, Ethiopia.

Vivero J.L., Ensermu Kelbessa and Sebsebe Demissew (2004). Red List of Endemic Flowering Plants of Ethiopia and Eritrea, $5^{\text {th }}$ Draft (Unpublished). National Herbarium, Addis Ababa University.
Sci. Technol. Arts Res. J., April-June 2013, 2(2): 58-69

Vivero, J.L., Ensermu Kelbessa and Sebesebe Demissew (2005). The Red list of Endemic Trees and Shrubs of Ethiopia and Eritrea. Fauna and Flora International, Cambridge, UK, Pp23.

W.D.A.R.D.O. (Wayu-Tuka District Agriculture and Rural Development Office) (2009). Socioeconomic profile of Wayu-Tuka District. Gute.

Woldeyohannes Enkossa (2008). Floristic analysis of Alata-Bolale Forest in Gudaya Billa Woreda, East Wollega, Oromia Regional State, West Ethiopia. M.Sc. Thesis (Unpublished), Addis Ababa University.

WRI, UNEP, UNDP, and WB (1998). World Resources 1998-99. Oxford University Press, New York.

Zerihun Woldu (2008). The Population, Health and Environment Nexus, The need for integration and networking. A background paper for the establishment and launching of PHE. Addis Ababa University. Pp. 34.

Zerihun Woldu, Feoli, E and Lisanework Nigatu (1989). Partitioning an elevational gradient of vegetation from southeastern Ethiopia by probabilistic methods. Vegetatio 81:189-198. 